TAPROBANICA, ISSN 1800-427X. October, 2010. Vol. 02, No. 02: pp. 86-94, 1 pl.

(C) Taprobanica Nature Conservation Society, 146, Kendalanda, Homagama, Sri Lanka.

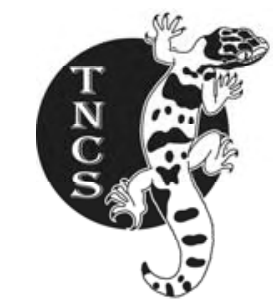

\title{
REPTILE DIVERSITY OF A FRAGMENTED LOWLAND RAIN FOREST PATCH IN KUKULUGALA, RATNAPURA DISTRICT, SRI LANKA
}

D. M. S. Suranjan Karunarathna ${ }^{1}$ and A. A. Thasun Amarasinghe ${ }^{2}$

\author{
${ }^{1}$ Nature Exploration \& Education Team, B-1 / G-6, De Soysapura, Morauwa 10400, Sri Lanka \\ E-mail: dmsameera@gmail.com \\ ${ }^{2}$ Taprobanica Nature Conservation Society, 146, Kendalanda, Homagama, Sri Lanka \\ E-mail: thasun.taprobanica@gmail.com
}

\begin{abstract}
A four month survey was undertaken to document the diversity and abundance of reptiles in the Kukulugala forest (KF) in the Ratnapura District, Sri Lanka. A total of 708 individuals belonging to 41 genera ( 50\%) and 13 families ( 55\%) were recorded. KF had high species diversity with 58 species, representing about $\sim 28 \%$ of the total diversity of known reptiles of Sri Lanka. Of the recorded species, $11(\sim 19 \%)$ were threatened and 24 ( 44\%) are endemic to Sri Lanka. Endemic relict genera including Aspidura, Balanophis, Cercaspis, Lyriocephalus, Ceratophora, Lankascincus and Nessia were also recorded during the survey. Availability of varied microhabitats may be responsible for the observed high species diversity. Anthropogenic activities, particularly illegal logging and man-made forest fires, is threatening these habitats leading to reduction in reptile population and diversity.
\end{abstract}

Keywords: Conservation, endemic, reptiles, threatened, wet-zone, Ratnapura, Sri Lanka

\section{Introduction}

Sri Lanka, despite its small area of $65,610 \mathrm{~km}^{2}$, has an estimated population of 18.7 million people (IUCN SL, 2005). It is among the biologically richest countries in South Asia and is considered as a global biodiversity hotspot along with the Western-Ghats (Bossuyt et al., 2004; Gunatilleke et al., 1995; Gunawardene et al., 2007; Meegaskumbura et al., 2002). Its natural forest areas still constitute a little over $12 \%$ of the total land area (Tan, 2005) and favorable environmental factors such as high rainfall, humidity, and high density of undergrowth found in these areas support a rich diversity of herpetofauna (Karunarathna et al., 2008). However, the natural forests in the island are rapidly diminishing as a result of the expansion of settlements and agricultural land, leading to 
adverse impacts on the rich biodiversity (Bambaradeniya et al., 2003; Giri \& Chaturvedi, 2001). The loss of natural forests and other causes over the past 100 years, has led to the extinction of nineteen species of the frog genus Pseudophilautus, and one species each from the genera Adenomus and Nannophrys (Manamendra-Arachchi \& Pethiyagoda, 2005; Meegaskumbura et al., 2007).

According to the IUCN SL \& MENR (2007) 16 species of reptiles in Sri Lanka (including 12 endemics) are critically endangered, 23 (including 16 endemics) are endangered, 17 (including 9 endemics) are vulnerable, 25 (including 15 endemics) are near threatened and 47 (including 37 endemics) are data deficient. Based on published sources, a total of 208 species of reptiles are recorded from Sri Lanka and 118 (56.7 \%) are known to be endemic to the island (De Silva, 2006; Maduwage et al., 2009; Manamendra-Arachchi et al., 2007; Wickramasinghe \& Munindradasa, 2007; Wickramasinghe et al., 2007).

The Wet Zone forests of Sri Lanka harbor more than $60 \%$ of the indigenous herpetofauna of Sri Lanka (Bambaradeniya, 2006; De Silva, 1996). Furthermore, a high percentage of endemism can be seen in the southwest lowland forests where almost $90 \%$ of the endemic vertebrates are concentrated (Bambaradeniya et al., 2003; IUCN SL \& MENR, 2007; Senanayake et al., 1977; Wijesinghe \& Dayawansa, 2002). Previous studies have focused on the avian, butterfly and fish diversity of Kukulugala Forest, one of the fragmented forest patches in lowland Wet Zone Sri Lanka (Jayaneththi \& Maduranga, 2004; Sirimanna, 2005). This study reports some preliminary data on herpetological diversity and the threats posed to the reptiles of Kukulugala. Its aim is to enhance the current knowledge of the biodiversity and conservation implications in this unique forest habitat.

\section{Study Area}

The Kukulugala Forest (KF) is situated within the Western boundary of Ratnapura District in Sabaragamuwa Province (Map 1); it is located 15 $\mathrm{km}$ away from Bulatsinhala town. The study area is located between $6^{\circ} 38^{\prime} 30.52^{\prime \prime}-6^{\circ} 40^{\prime} 51.00^{\prime \prime} \mathrm{N}$ and $80^{\circ} 15^{\prime} 07.39^{\prime \prime}-80^{\circ} 17^{\prime} 35.25^{\prime \prime} \mathrm{E}$. The forest ecosystem, which also forms an important part of the forest cover of the Dumbara-Manana village (Sirimanna, 2005), covers an area of more than 600 acres within the Ayagama secretariat division and can be categorized as a lowland evergreen rain forest (Gunatilleke \& Gunatilleke, 1990). This lowland wet forest consists of dominant tree species such as Dipterocarpus sp., Mesua sp., Doona sp., Schumacheria castaneifolia, Artocarpus nobilis, Calophyllum inophyllum, Mangifera zeylanica, Humboldtia laurifolia, Oncosperma fasciculatum, Canarium zeylanicum and Shorea sp. (Karunarathna \& Amarasinghe, 2007).

The general forest floor is covered with cascading large boulders and leaf litter. Kukulugala Mountain, also known as "Horanae Kanda" (Horana = traditional bugle, Kanda $=$ mountain) in Sinhala language, is situated at an elevation of $705 \mathrm{~m}$ a.s.l. The area supports a rich network of waterways which includes two waterfalls called "Ritigas Ella" and "Miyunu Ella" (Ella = fall). Among the number of small streams which start from this mountain, "Thaberum ela" and "Era-Handapana ela" (Ela = stream) are the major tributaries that flow throughout the year (Jayaneththi \& Maduranga, 2004; Karunarathna et al., 2004). The average annual rainfall is around $3849 \mathrm{~mm}$, with most rainfall occurring from December to May. The weather gradually becomes dry from July to October when the highest temperatures are recorded. The mean annual temperature in the $\mathrm{KF}$ is $28.7^{\circ} \mathrm{C}$ with a maximum of $32{ }^{\circ} \mathrm{C}$ and a minimum of $24.3{ }^{\circ} \mathrm{C}$. The study area is accessible via the Horana - Bulathsinhala road or via the Rathnapura - Panadura road (Jayaneththi \& Maduranga, 2004).

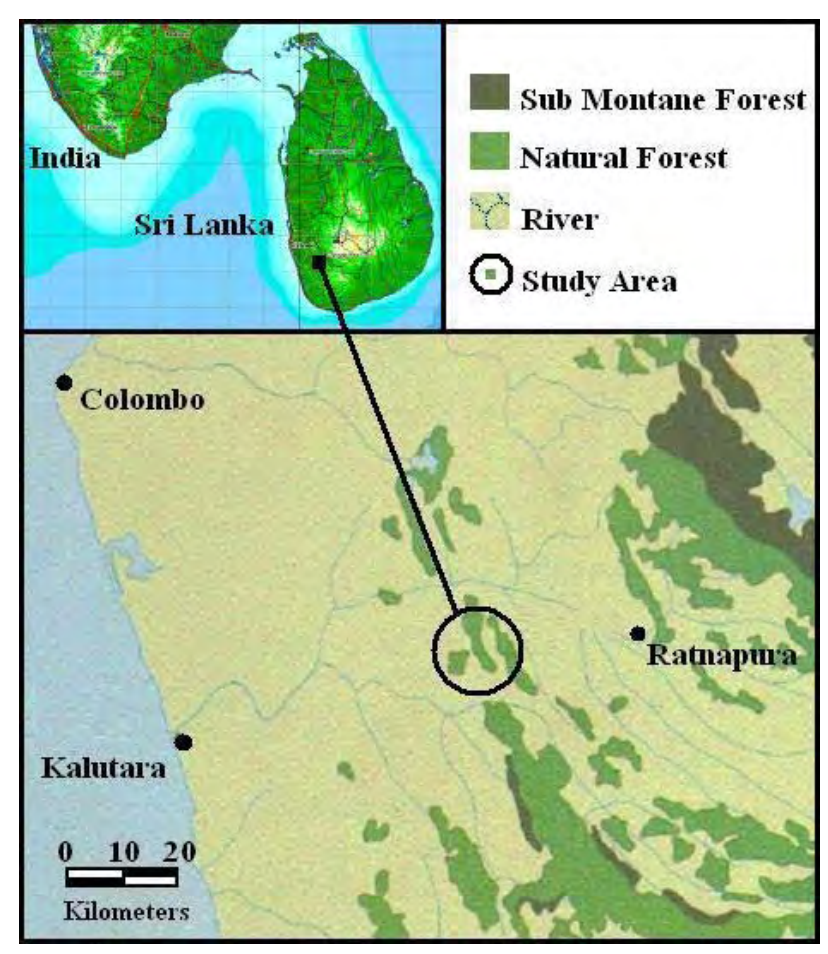

Map 1: Study Area, Kukulugala Forest 


\section{Materials and Methods}

The present study was carried out during the period of November 2001 to February 2002. Fieldwork was conducted for a total of 20 days (9 hrs / day) over the 4 month study period. Each field visit comprised of four night and two day surveys per week (two field visits per month $\mathrm{x} 3$ habitat). General area surveys were carried out in three elevation types (below $<200 \mathrm{~m}$, between 200m $400 \mathrm{~m}$ and $>400 \mathrm{~m}$ ) and were sampled using $100 \times 2$ $\mathrm{m}$ transects (Table 1). Approximately an hour was spent at each of the 72 randomly selected transects that were located within the several habitat types found in the area. Surveys were conducted by both day and night. Flashlights were used at night.

The surveys were conducted by visual encounter survey (VES). All habitats such as water bodies, rock crevices, logs, trees, decaying vegetation and bushes up to $5 \mathrm{~m}$, were thoroughly searched for the presence of reptiles and amphibians. All collected specimens were examined carefully and recorded before being released back into the same habitat. Specimens were examined using a $10 \times$ Triplet $^{\circledR}$ hand lens and all species and color morphs were photographed alive using a digital camera (Sony DHC H9). The species were identified using keys and guides provided by Deraniyagala (1953, 1955), Das \& De Silva (2005), De Silva (1980), De Silva (1990), Greer (1991), and Wickramasinghe \& Somaweera (2003). Afterwards the same species were verified using keys and guides provided by Bahir \& Maduwage (2005), Bahir \& Silva (2005), Bauer et al. (2010), Maduwage et al. (2009), Manamendra-Arachchi et al. (2007), Rooijen \& Vogel (2008), Vidal et al. (2009), Vogel \& David (2006) and Wickramasinghe \& Munindradasa (2007). Abundance was assessed according to the total number of individuals of each species recorded throughout the study period.

\section{Results}

During the present survey a total of 58 (27.8\%) species of reptiles, representing 33 (57\%) species of the Sri Lankan serpentoid reptiles and 25 (43\%) of the Sri Lankan species of tetrapod reptiles were recorded from the main ecosystems of the KF (Table 2). They belong to 13 (54.1\%) families, 41 (50.6\%) genera and include 24 (41.3\%) endemic species (13 - serpentoid reptiles and 11 - tetrapod reptiles). The endemic relict genera; Aspidura (1 sp.), Balanophis (1 sp.), Cercaspis (1 sp.), Nessia (1 sp.), Lyriocephalus (1 sp.), Ceratophora (1 sp.) and Lankascincus (2 sp.) were found in KF. Out of the 58 species recorded in KF, 11 (18.9\%) were
Threatened species, 4 (6.8\%) were Endangered species and 7 (12.1\%) were Vulnerable species according to IUCN SL \& MENR (2007). The reptile fauna of the KF is composed of 2 tortoise, 23 lizards and 33 snake species. The relationships of these species are diverse. Some, such as Geckoella triedrus, Aspidura guentheri, Balanophis ceylonensis, Oligodon calamarius, Lankascincus gansi and Otocryptis wiegmanni occur in the same habitat at the same elevation. Different families recorded a different number of species as follows (proportional representation); Bataguridae (1 sp.) 1.7\%, Trionychidae (1 sp.) 1.7\%, Agamidae (6 sp.) 10.3\%, Gekkonidae (9 sp.) 15.5\%, Varanidae (2 sp.) $3.4 \%$, Pythonidae (1 sp.) 1.7\%, Typhlopidae (1 sp.) $1.7 \%$, Cylindrophidae (1 sp.) 1.7\%, Elapidae (2 sp.) 3.4\%, Viperidae (4 sp.) 6.9\%, Scincidae (6 sp.) 10.3\%, Colubridae (18 sp.) $31.0 \%$ and Natricidae (6 sp.) $10.3 \%$.

\section{Discussion}

According to the present survey the most abundant families were Colubridae (167 individuals, 23.6\%) and Gekkonidae (140) 19.8\%, while other families Cylindrophidae (10) 1.4\%, Trionychidae (11) 1.6\%, Bataguridae (13) 1.8\%, Pythonidae (13) $1.8 \%$ and Varanidae (20) 2.8\% were the least abundant. The lower diversity of the upper forest habitats $(>400$ m) may be due to the open canopy resulting in the exposure of the forest floor to high temperature and winds, resulting in increased disturbance, desiccation and predation. Melanochelys trijuga, Lissemys punctata, Varanus salvator, Atretium schistosum, Xenochrophis asperrimus and Xenochrophis cf. piscator species were not recorded in the upper part of the forest area. This may be due to the lack of large water bodies. Chrysopelea ornata and Liopeltis calamaria snake species were recorded only once during the study period.

Hemiphyllodactylus typus and Lepidodactylus lugubris are parthenogenetic geckos that are restricted to large boulders and crevices of old houses in the KF. Cnemaspis molligodai, C. silvula and Hemidactylus depressus are distributed moderately both inside the forest and in the houses of the human inhabitants. Geckoella triedrus was only observed under large logs on the forest floor. The second most recorded species, Hemidactylus parvimaculatus, was found occupying every conceivable niche (terrestrial and arboreal) within the KF. Several gecko eggs were observed in rock crevices in the middle area of the forest. The villagers in the study area have an aversion to 
geckos, whether through superstition or squeamishness.

Melanochelys trijuga and Lissemys punctata are generally active during the rainy season and found in the vicinity of temporary water bodies. Calotes liolepis and Lyriocephalus scutatus are diurnal, arboreal lizards commonly found in undisturbed closed canopy forest. The litter dwelling Ceratophora aspera is easily camouflaged by the dark brown leaf litter in very shaded areas and is generally found in couples but during this survey only a single specimen was recorded. Otocryptis wiegmanni was generally found in shady places near streams, where some egg clutches were also recorded. They generally dig holes in the sandy soil into which they lay $3-6$ eggs at a time. During some night surveys groups of Cercaspis carinatus were observed digging the soil and feeding on the eggs of Otocryptis wiegmanni. This indicates that Cercaspis carinatus are social feeders. This behavior was also observed during a previous survey at Beraliya Mukalana forest (Karunarathna et al., 2008).

\section{Shortcomings of the study}

Most of the species were recorded after a shower of rain, particularly in the well-shaded canopy covered areas. Several species were also recorded within the well-wooded home gardens that were dominated by native plant species. As most of the sampling was conducted during the day time, the data collection was biased towards lizards. Had we spent equal time at these sites at night the snake species recorded would probably have been higher. Even diurnal snakes are most easily found at night while sleeping in vegetation where their camouflage is less effective in torch light.

\section{Threats and Recommendations}

It is evident that the KF provides suitable habitat, particularly for reptiles. Habitat loss and deterioration remain the dominant threat to $\mathrm{KF}$ reptile populations at the present time. Some areas of the KF are being felled to clear land for tea and rubber plantations. This poses a major threat not only for reptiles but also for the other flora and fauna of the area and its surrounds. In addition, the villagers kill snakes that have been incorrectly identified. This preliminary survey indicates that the KF has a high reptilian diversity. However, this study was conducted over a short period of time and therefore, it is recommended that further surveys are conducted over longer periods to truly assess the reptilian diversity in the area.
Based on IUCN SL \& MENR (2007) criteria 4 ( 7\%) Endangered and 7 ( 12\%) Vulnerable species have been recorded in this study. This is a critical finding of KF. The slash and burn technique of shift cultivation involves intermittent clearing of a forest patch for agricultural practices, which destroys the habitat of several endemic and relict reptile genera (Gunatilleke et al., 1995). This and other human activities involving cutting of trees inside the forest will contribute to the decline of tree-dwelling reptiles, particularly those belonging to the genera Boiga, Calotes, Cnemaspis, Hemiphyllodactylus and Lyriocephalus that already show irregular distribution due to their habitat specificity.

It is recommended that awareness programs on managing the forest and its resources are conducted for the local communities that will in turn contribute to the protection of these species. An advantage of using members of the local communities in future monitoring is that it will help to raise awareness of the value of species and habitats. If this awareness can be integrated into conservation and management efforts, then the likelihood of its success will be higher than otherwise might be the case. Measures should also be taken to declare the $\mathrm{KF}$ as a Forest Reserve under the Forest Department due to its high diversity of endemic and threatened species.

\section{Acknowledgements}

The authors wish to thank Sujan Maduranga (North Dhakota University), Asha De Vos (IUCN) for reviewing the manuscript and Jayantha Wattevidanage (OUSL) for guidance. We also like to thank Mendis Wickramasinghe (HFS) and Naalin Perera, (IUCN) for giving us literature and more comments. Finally we thank Thalagala Dhamma Gaveshi Thera, Ramyanath Sirimanna, Anushka Kumarasinghe, Tiran Abeywardena, Panduka Silva, late Sirikumara, Niranjan Karunarathna and Bandula Jayaneththi (YZA) for the helps during the field work in KF area in different ways.

\section{Literature Cited}

Ashton, M., C. V. S Gunatileke, N. De Zoysa, M. D. Dassanayake, N. Gunatileke and S. Wijesundara, 1997. A field guide to the common trees and shrubs of Sri Lanka. Wildlife Heritage Trust of Sri Lanka, Colombo: 432.

Bahir, M. M. and K. P. Maduwage, 2005. Calotes desilvai, a new species of agamid lizard from Morningside Forest, Sri Lanka. In: Yeo, D. C. J., P. K. 
L. Ng and R. Pethiyagoda (Eds.). Contributions to biodiversity exploration and research in Sri Lanka. The Raffles Bulletin of Zoology, Supplement No. 12: 381-392.

Bahir, M. M. and A. Silva, 2005. Otocryptis nigristigma, a new species of agamid lizard from Sri Lanka. In: Yeo, D. C. J., P. K. L. Ng and R. Pethiyagoda (Eds.). Contributions to biodiversity exploration and research in Sri Lanka. The Raffles Bulletin of Zoology, Supplement No. 12: 393-406.

Bambaradeniya, C. N. B. (Ed.)., 2006. Species richness of Fauna in Sri Lanka: Current status and future prospects. In: Bambaradeniya, C. N. B. (Ed.). Fauna of Sri Lanka: Status of Taxonomy, Research and Conservation. IUCN Sri Lanka: X-XI.

Bambaradeniya, C. N. B., M. S. J. Perera, W. P. N. Perera, L. J. M. Wickramasinghe, L. D. C. B. Kekulandala, V. A. P. Samarawickrema, R. H. S. S. Fernando and V. A. M. P. K. Samarawickrema, 2003. Composition of faunal species in the Sinharaja world heritage site in Sri Lanka. Sri Lanka Forester, 26: 2140.

Bauer, A. M., T. R. Jackman, E. Greenbaum, V. B. Giri \& A. De Silva, 2010. South Asia supports a major endemic radiation of Hemidactylus geckos. Molecular Phylogenetics and Evolution, 57: 343-352.

Bossuyt, F., M. Meegaskumbura, N. Beenaerts, D. J. Gower, R. Pethiyagoda, K. Roelants, A. Mannaert, M. Wilkinson, M. M. Bahir, K. Manamendra-Arachchi, P. K. L. Ng, C. J. Schneider, O. V. Oommen and M. C. Milinkovitch, 2004. Local endemism within the Western Ghats-Sri Lanka Biodiversity Hotspot. Science, 306: 479-481.

Das, I. and A. de Silva, 2005. Photographic guide to the Snakes and other Reptiles of Sri Lanka. New Holland Publishers, Uk: 144.

Deraniyagala, P. E. P., 1953. A Colored Atlas of Some Vertebrates from Ceylon, Tetrapod Reptilia, Vol - 2. National Museums of Sri Lanka: 101.

Deraniyagala, P. E. P., 1955. A Colored Atlas of Some Vertebrates from Ceylon, Serpentoid Reptilia, Vol - 3. The National Museums of Sri Lanka: 121.

de Silva, A., 1990. Colour Guide to the snakes of Sri Lanka. R \& A Publishing Ltd, Avon, England: 130.

de Silva, A., 1996. The Herpetofauna of Sri Lanka: a brief review. Graphic Land, Kandy. Sri Lanka: 99. de Silva, A., 2006. Current status of the Reptiles of Sri Lanka. In: Bambaradeniya, C. N. B. (Ed.). Fauna of Sri Lanka: Status of Taxonomy, Research and Conservation. IUCN Sri Lanka: 134-163.

de Silva, P. H. D. H., 1980. Snakes Fauna of Sri Lanka, with special reference to skull, dentition and venom in snakes. The National Museums of Sri Lanka: 472.

Giri, V. and N. Chaturvedi, 2001. Preliminary survey of the Herpetofauna in the Western Ghats region of Maharashtra. Tigerpaper, 8 (2): 1-7.

Greer, A. E., 1991. Lankascincus, a new genus of Scincid lizards from Sri Lanka with descriptions of three new species. Journal of Herpetology, 25 (1): 5964.

Gunatilleke, I. A. U. N., P. B. Karunaratne and C. V. S. Gunatilleke, 1995. Status of natural habitats in relation to the Herpetofauna of Sri Lanka. Lyriocephalus, 2 (1\&2): 71-80.

Gunatilleke, I. A. U. N. and C. V. S. Gunatilleke, 1990. Distribution of Floristic Richness and its Conservation in Sri Lanka. Conservation Biology, 4 (1): 21-31.

Gunawardene, N. R., A. E. D. Daniels, I. A. U. N. Gunatilleke, C. V. S. Gunatilleke, P. V. Karunakaran, K. G. Nayak, S. Prasad, P. Puyravaud, B. R. Ramesh, K. A. Subramanian and G. Vasanthy, 2007. A brief overview of the Western Ghats-Sri Lanka biodiversity Hotspot. Current Science, 93 (11): 1567-1572.

IUCN SL, 2000. The 1999 Red List of Threatened Fauna and Flora of Sri Lanka. Colombo, IUCN Sri Lanka: 113.

IUCN SL, 2005. Marine turtle conservation strategy and action plan for Sri Lanka. Department of Wildlife Conservation and IUCN Sri Lanka: 79.

IUCN SL \& MENR, 2007. The 2007 Red List of Threatened Fauna and Flora of Sri Lanka. Colombo, Sri Lanka: 148.

Jayaneththi, H. B. and H. G. S. Maduranga, 2004. A preliminary study on the diversity of Ichthyofauna of Kukulugala proposed forest reserve, Ratnapura district. Sri Lanka Naturalist, 6 (1\&2): 17-23.

Karunarathna, D. M. S. S. and A. A. T. Amarasinghe, 2007. A study of the Reptilian faunal diversity in Kukulugala isolated hill forest, Ratnapura District in Sri Lanka. Proceedings of the $12^{\text {th }}$ International 
Forestry and Environment Symposium, University of Sri Jayewardenepura, Sri Lanka: 24-25.

Karunarathna, D. M. S. S., U. T. I. Abeywardena, A. A. T. Amarasinghe, D. G. R. Sirimanna and M. D. C. Asela, 2008. Amphibian faunal diversity of Beraliya Mukalana Proposed Forest Reserve. Tigerpaper, 35 (2): 12-16.

Karunarathna, D. M. S. S., D. H. P. U. Silva, H. T. A. P. Peiris, M. D. C. Asela, U. T. I. Abeywardena, A. A. D. A. Udayakumara, D. G. R. Sirimanna and W. C. C. Soysa, 2004. Two new sightings of Liopeltis calamaria (Reptilia: Colubridae) from Sri Lanka. Loris, 23 (5\&6): 23-26.

Maduwage, K., A. Silva, K. Manamendra-Arachchi and R. Pethiyagoda, 2009. A taxonomic revision of the South Asian hump-nosed pit vipers (Squamata: Viperidae: Hypnale). Zootaxa, 2232: 1-28.

Manamendra-Arachchi, K. and R. Pethiyagoda, 2005. The Sri Lankan shrub-frogs of the genus Philautus Gistel, 1848 (Ranidae: Rhacophorinae) with description of 27 new species. In: Yeo, D. C. J., P. K. L. Ng, and R. Pehiyagoda (Eds.). Contribution to Biodiversity Exploration and Research in Sri Lanka. The Raffles Bulletin of Zoology, Supplement 12: pp. 163-303.

Manamendra-Arachchi, K., S. Batuwita and R. Pethiyagoda, 2007. A taxonomic revision of the Sri Lanka Day-geckos (Reptilia: Gekkonidae: Cnemaspis), with description of new species from Sri Lanka and Southern India. Zeylanica, 7 (1): 9-122.

Meegaskumbura, M., F. Bossuyt, R. Pethiyagoda, K. Manamendra-Arachchi, M. M. Bahir, M. C. Milinkovitch and C. J. Schneider, 2002. Sri Lanka: an amphibian hotspot. Science, 298: 379.

Meegaskumbura, M., K. Manamendra-Arachchi, C. J. Schneider and R. Pethiyagoda, 2007. New species amongst Sri Lanka's extinct shrub frogs (Amphibia: Rhacophoridae: Philautus). Zootaxa, 1397: 1-15.

Senanayake, F. R., M. Soule and J. W. Senner, 1977. Habitat values and endemicity in the vanishing rainforest of Sri Lanka. Nature, 265: 351-354.

Senaratna, L. M., 2001. A Check List of the Flowering Plants of Sri Lanka, National Science Foundation, Sri Lanka: 342.

Sirimanna, D. G. R., 2005. An Avifaunal study of the Kukulugala proposed forest reserve, Ratnapura District, Sri Lanka. Loris, 24 (1\&2): 29-32.
Tan, B. C., 2005. New species records of Sri Lanka Mosses. In: Yeo, D. C. J., P. K. L. Ng, and R. Pethiyagoda (Eds.). Contribution to Biodiversity Exploration and Research in Sri Lanka. The Raffles Bulletin of Zoology, Supplement 12: 5-8.

Van Rooijen, J. and G, Vogel, 2008. An investigation into the taxonomy of Dendrelaphis tristis (Daudin, 1803): revalidation of Dipsas schokari (Kuhl, 1820) (Serpentes, Colubridae). Contributions to Zoology, 77 (1): 33-43.

Vidal, N., J. C. Rage, A. Couloux and S. B. Hedges, 2009. Snakes (Serpentes). In: Hedges, S.B. and S. Kum (Eds.). The Timetree of Life. Oxford University Press. 390-397.

Vogel, G. and P. David, 2006. On the taxonomy of the Xenochrophis piscator complex (Serpentes, Natricidae). In: Vences, M., J. Köhler, T. Ziegler and W. Böhme (Eds.). Herpetologia Bonnensis II, Proceedings of the 13th Congress of the Societas Europaea Herpetologica, 13: 241-246.

Wickramasinghe, L. J. M. and R. K. Somaweera, 2003. Distribution and Current Status of the Endemic Geckos of Sri Lanka. Gekko 3 (1): 2-13.

Wickramasinghe L. J. M. and D. A. I. Munindradasa, 2007. Review of the genus Cnemaspis Strauch, 1887 (Sauria: Gekkonidae) in Sri Lanka, with the description of five new species. Zootaxa, 1490: 1-63.

Wickramasinghe L. J. M., R. K. Rodrigo, N. Dayawansa and U. L. D. Jayantha, 2007. Two new species of Lankascincus (Squamata: Scincidae) from Sripada Sanctuary (Peak Wilderness), in Sri Lanka. Zootaxa, 1612: 1-24.

Wijesinghe, M. R. and P. N. Dayawansa, 2002. The amphibian fauna at two altitudes in the Sinharaja rainforest, Sri Lanka. Herpetological Journal, 12: 175-178. 
Table 1: Description of the habitat types in three study areas of KF in Ratnapura District, Sri Lanka [Based on the Ashton et al. (1997); Gunatilleke \& Gunatilleke (1990) and Senaratna (2001)].

\section{Study Area}

\section{Description of Habitat}

Mixed cropping with woody and non woody plants like Mangifera indika, Artocarpus heterophyllus, Dipterocarpus sp., Chaetocarpus sp., Myristica sp. and Cinnamomun sp. Lower area of KF trees growing up to $25 \mathrm{~m}$, shade is about 60\%, and leaf litter content is high and moderately (below 200m) wet. Among the most abundant understorey tree species are Garcinia spp and Gyrinops spp. In the lowland forest area of KF are perennial flowing water bodies, $1 \mathrm{~m}$ to $10 \mathrm{~m}$ wide. Home garden also included rarely.

Middle area of KF (between 200m-400m)
Plants such as Dipterocarpus sp., Chaetocarpus sp., Mesua sp., Myristica sp., Shorea sp. and Calophyllum sp. trees very dominant, growing up to $40 \mathrm{~m}$, shade is about $80 \%$, and leaf litter content is very high and wet. Flowing water bodies, $1 \mathrm{~m}$ to $4 \mathrm{~m}$ wide, visibility high, and turbidity low. Large rock boulder areas with seasonally moist cascade habitats

Plants such as Strobilanthes sp. are very dominant. Rock boulders and grassy areas with Upper area of KF $5 \mathrm{~m}$ tall are randomly distributed on open soil. Bamboo species along with those of (above 400m) Eriocaulon sp. and Osbeckia sp. are also common in the open grasslands near rocky outcrops. Leaf litter content is very low and dry, flowing water bodies, $1 \mathrm{~m}$ or $2 \mathrm{~m}$ wide

Table 2: Checklist of the reptile fauna recorded from KF. (Abbreviation: TR - threatened / † endemic genus / * endemic species / VR - very rare / R - rare / UC - uncommon / C - common / VC - very common) species. (Source: IUCN, 2000; IUCN \& MENR, 2007).

\begin{tabular}{lllcc}
\hline Family and & Common & Status & Status IUCN & Total Individuals Species \\
Scientific Name & Name & IUCN & \& MENR & with \% \\
& & $(2000)$ & $(2007)$ & Abundance \\
\hline
\end{tabular}

\section{Tortoises and Turtles}

\section{Bataguridae}

Melanochelys trijuga

Black Turtle

TR

13 (1.83)

C

\section{Trionychidae}

Lissemys punctata

Flapshell Turtle

TR

VU

$11(1.55)$

C

Lizards

Agamidae
Calotes calotes
Calotes liolepis
Calotes versicolor
Ceratophora aspera
Lyriocephalus scutatus
Otocryptis wiegmanni

Green Garden Lizard

Whistling Lizard *

Common Garden Lizard

Rough Horn Lizard *†

Hump Snout Lizard *†

Sri Lankan kangaroo Lizard *

$\begin{array}{ll}\text { TR } & \text { VU } \\ \text { TR } & \text { EN } \\ \text { TR } & \\ \text { TR } & \end{array}$

24 (3.38)

VC

$3(0.42) \quad \mathrm{R}$

31 (4.37) VC

$3(0.42) \quad R$

$5(0.70) \quad \mathrm{R}$

13 (1.83) C 


\section{Gekkonidae}

Cnemaspis molligodai

Cnemaspis silvula

Geckoella triedrus

Gehyra mutilata

Hemidactylus parvimaculatus

Hemidactylus depressus

Hemidactylus frenatus

Hemiphyllodactylus typus

Lepidodactylus lugubris

\section{Scincidae}

Lankascincus fallax

Lankascincus gansi

Lygosoma punctatus

Eutropis carinata

Eutropis macularia

Nessia burtonii

\section{Varanidae}

Varanus bengalensis

Varanus salvator

Snakes

\section{Pythonidae}

Python molurus

Typhlopidae

Ramphotyphlops braminus

Common Blind Snake

Gans's Lanka Skink *†

Dotted Skink

Common Skink

Bronzegreen Little Skink

Threetoe Snake Skink *†

Land Monitor

Water Monitor
TR

18 (2.54) VC

EN $29(4.09) \quad \mathrm{VC}$

TR

$2(0.28) \quad$ VR

$11(1.55) \quad \mathrm{C}$

38 (5.36) VC

10 (1.41) UC

22 (3.10) VC

$3(0.42) \quad \mathrm{R}$

7 (0.98) UC

56 (7.90) VC

$6(0.84) \quad \mathrm{UC}$

16 (2.25) VC

18 (2.54) VC

10 (1.41) UC

$3(0.42) \quad \mathrm{R}$

12 (1.69) C

8 (1.12) UC

\section{Cylindrophidae}

Cylindrophis maculatus

Sri Lanka Pipe Snake *

\section{Colubridae}

Ahaetulla nasuta

Ahaetulla pulverulenta

Green Vine Snake

Brown Vine Snake

Boiga ceylonensis

Boiga forsteni

Cercaspis carinatus

Chrysopelea ornata

Coelognathus helena

Dendrelaphis bifrenalis

Dendrelaphis caudolineolatus

Dendrelaphis schokari

Liopeltis calamaria

Lycodon aulicus

Sri Lanka Cat Snake

Forsten's Cat Snake

The Sri Lanka Wolf Snake *†

TR

Ornate Flying Snake

Trinket Snake

Boulenger's Bronze Back *

Gunther’s Bronze Back

Common Bronze Back

Gunther's Reed Snake

Common Wolf Snake

TR
TR

10 (1.41) UC

TR

13 (1.83)

C

24 (3.38) VC

$16(2.25) \quad \mathrm{VC}$

2 (0.28) VR

$6(0.84) \quad \mathrm{UC}$

$4(0.56) \quad \mathrm{R}$

VU

$11(1.55) \quad \mathrm{C}$

$1(0.14) \quad$ VR

19 (2.68) VC

7 (0.98) UC

VU

$4(0.56) \quad \mathrm{R}$

15 (2.11) C

VU

$1(0.14) \quad$ VR

$13(1.83) \quad \mathrm{C}$ 
Lycodon osmanhilli

Oligodon arnensis

Oligodon calamarius

Oligodon sublineatus

Ptyas mucosa

Sibynophis subpunctatus

\section{Natricidae}

Amphiesma stolatum

Aspidura guentheri

Atretium schistosum

Balanophis ceylonensis

Xenochrophis asperrimus

Xenochrophis cf. piscator

\section{Elapidae}

Bungarus ceylonicus

Naja naja

\section{Viperidae}

Hypnale hypnale

Hypnale zara

Trimeresurus trigonocephalus

Daboia russelli
Flowery Wolf Snake *

Common Kukri Snake

Templeton's Kukri Snake*

Dumerul's Kuki Snake *

Common Rat Snake

Jerdon's Polyodent

Buff Striped Keelback

Ferguson's Roughside *†

TR

Olive Keelback Watersnake

TR

Sri Lanka Keelback *†

Sri Lanka checkered Keelback *

TR

Checkered Keelback *

Sri Lankan Krait *

TR

Common Cobra

Merrem's Hump Nosed Viper

Lowland Hump Nosed Viper *

Green Pit Viper *

TR

Russell's Viper

TR

TR

TR
VU

9 (1.27)

$11(1.55)$

$5(0.70)$

$5(0.70) \quad R$

28 (3.95) VC

10 (1.41) UC

13 (1.83) C

4 (0.56) R

$14(1.97) \quad \mathrm{C}$

$3(0.42) \quad \mathrm{R}$

$16(2.25) \quad \mathrm{VC}$

12 (1.69)

C

$3(0.42) \quad \mathrm{R}$

22 (3.10) VC

$11(1.55) \quad$ C

5 (0.70) UC

7 (0.98) UC

12 (1.69) C 


\section{PLATE 05}

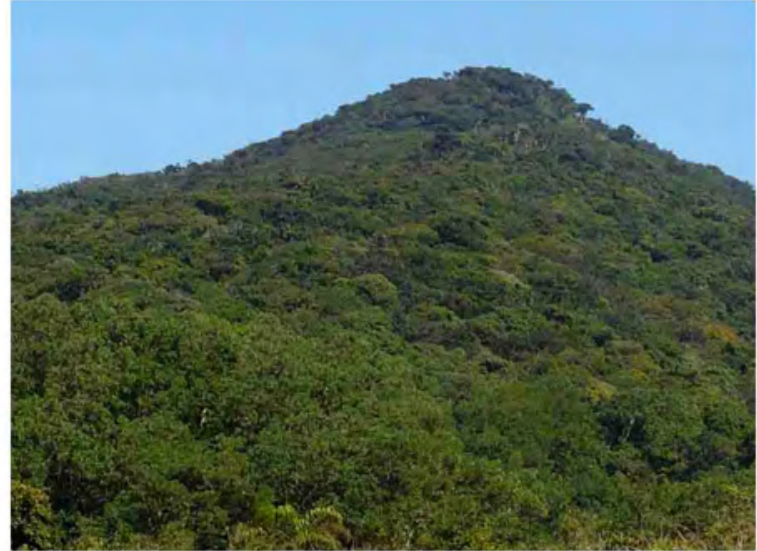

Fig. 01: Kukulugala Mountain

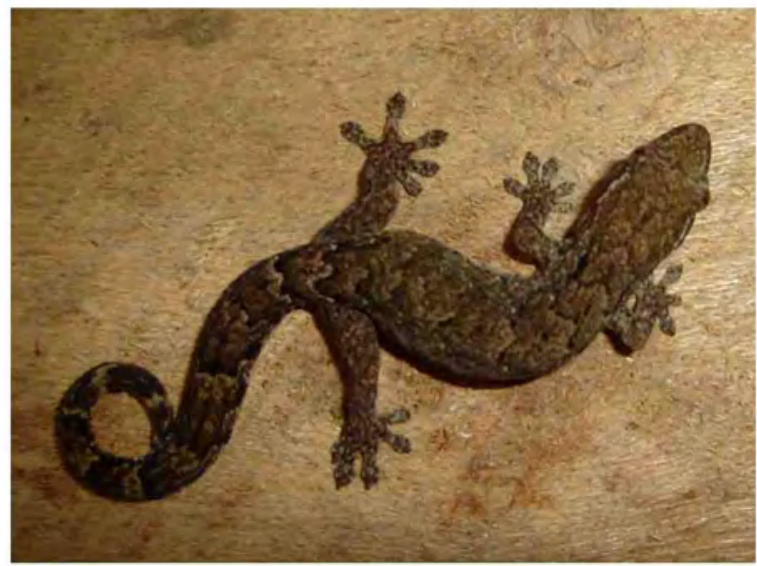

Fig. 03: Lepidodactylus lugubris

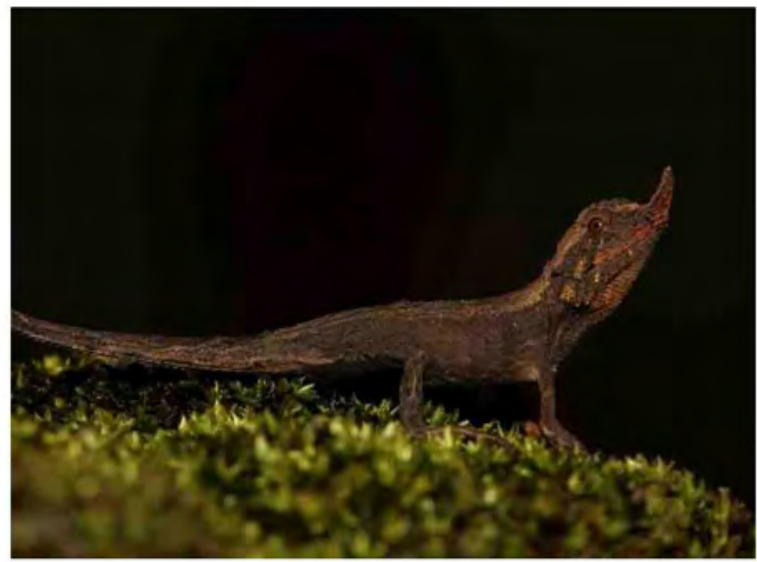

Fig. 05: Ceratophora aspera

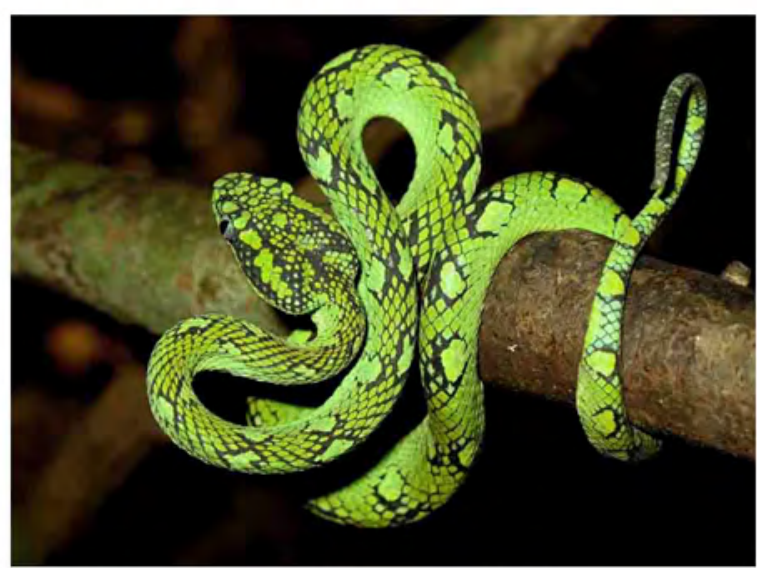

Fig. 07: Trimeresurus trigonocephalus

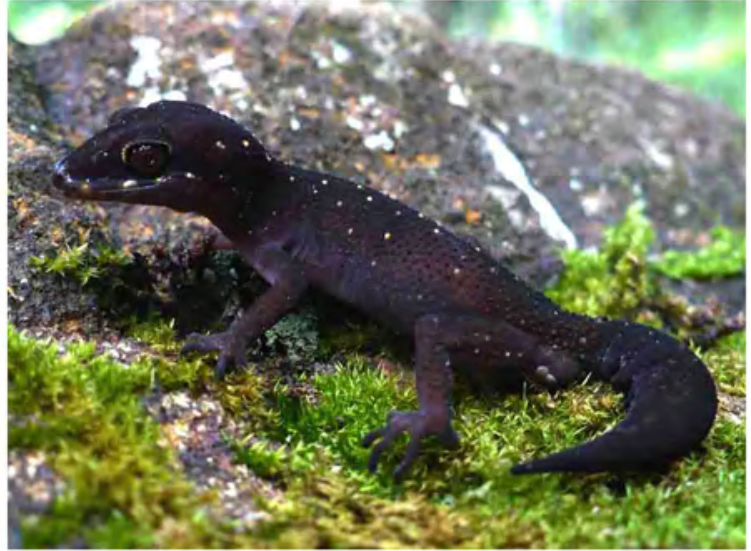

Fig. 02: Geckoella triedrus

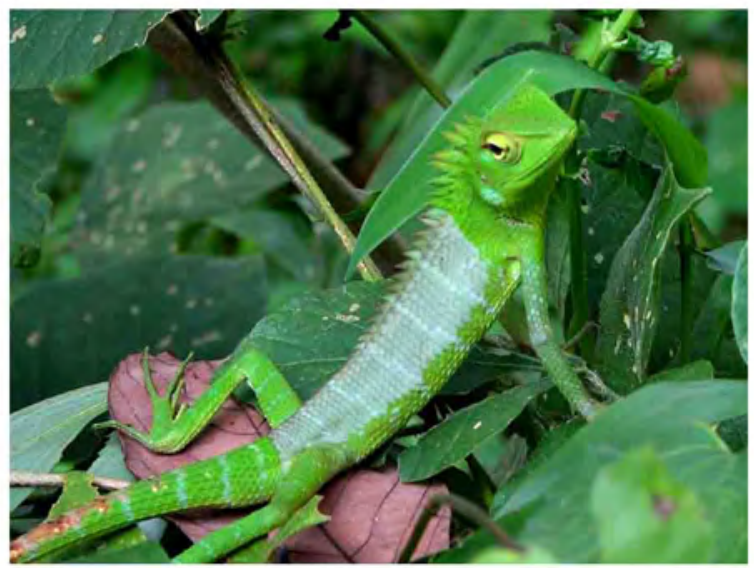

Fig 04: Calotes calotes

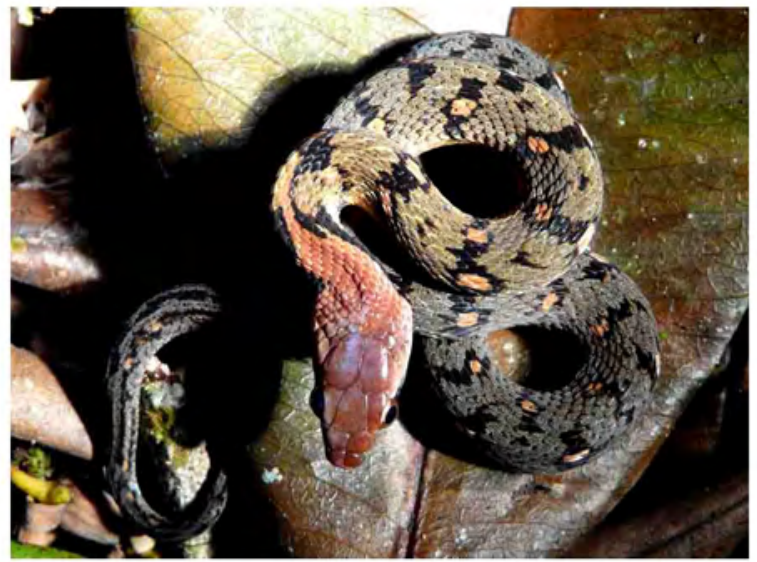

Fig. 06: Balanophis ceylonensis

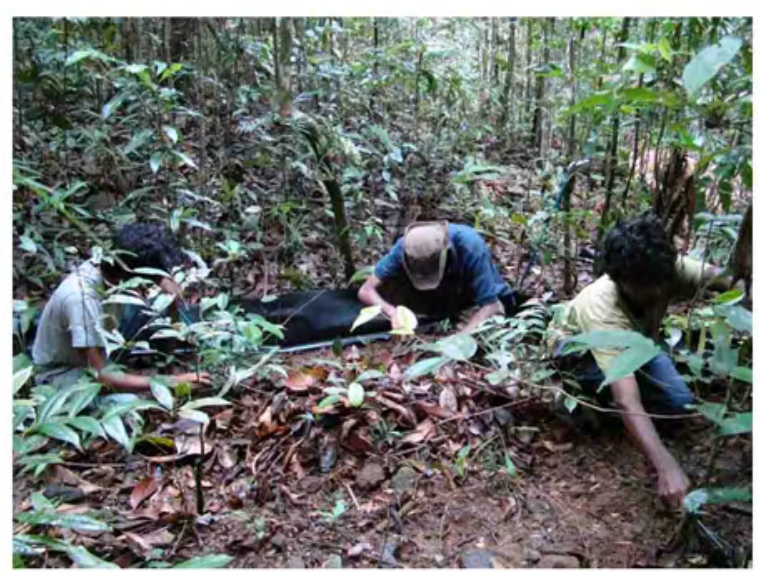

Fig. 08: Field work in Kukulugala forest 